\title{
Kewenangan Pemberian Izin Penggunaan Ruang Bawah Tanah dalam Proyek Mass Rapid Transit Jakarta
}

\author{
Triasita Nur Azizah \\ University of Jember, Indonesia \\ triasitanur@gmail.com
}

Iwan Rachmad Soetijono

University of Jember, Indonesia

iwan.fh@unej.ac.id

\author{
Rosita Indrayati \\ University of Jember, Indonesia \\ rosita.indrayati@yahoo.com
}

\begin{abstract}
As the capital of Indonesia, DKI Jakarta is classified as having the highest population density which resulted in the emergence of problems in the field of transportation, one of which is traffic congestion. The density of the land surface makes the use of basements an alternative in solving congestion problems in DKI Jakarta. In terms of licensing the use of underground space used by PT Mass Rapid Transit Jakarta (MRT) as the responsibility of MRT infrastructure implementation and procurement, the authorized licensing is governor through governor regulation. From a legal perspective, the main problem is that there is no clear legislation regarding the use and utilization of the basement. Therefore, an analysis of the licensing mechanism of the governor is required and the conformity of regulations issued by the governor with the legislation pertaining to the crypt. With normative juridical research, this article argues that those authorized to grant permits for the use of basements in an area are the governors concerned and not contrary to the laws and regulations governing them. The results of the study indicate that the mechanism of licensing the use of basements has been in accordance with the laws and regulations through the regional authority to implement the regional autonomy.
\end{abstract}

KEYWORD: Underground, Power of Local Government, Permissions.

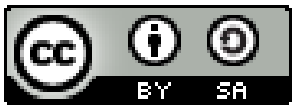

Copyright $\odot 2018$ by Author(s)

This work is licensed under a Creative Commons Attribution-ShareAlike 4.0 International License. All writings published in this journal are personal views of the authors and do not represent the views of this journal and the author's affiliated institutions.

\section{HOW TO CITE:}

Azizah, Triasita Nur, Iwan Rachmad Soetijono \& Rosita Indrayati. "Kewenangan Pemberian Izin Penggunaan Ruang Bawah Tanah dalam Proyek Mass Rapid Transit Jakarta" (2018) 5:2 Lentera Hukum 307-322.

Submitted: January 15, 2018 Revised: February 13, 2018 Accepted: July 12, 2018 


\section{PENDAHULUAN}

Wilayah Negara Kesatuan Republik Indonesia meliputi udara, laut, dan darat yang termasuk juga ruang di dalam bumi. Maka negara wajib melakukan pengelolaan yang sebesar-besarnya demi kemakmuran rakyat. Sebagaimana dalam Pasal 33 ayat (3) Undang-Undang Dasar Negara Republik Indonesia Tahun 1945 (UUD 1945), menegaskan bahwa sumber daya alam yang dikuasai oleh negara dipergunakan secara keseluruhan untuk fungsi kemakmuran rakyat. Maka dalam ini, dibuatlah UndangUndang Nomor 26 Tahun 2007 tentang Penataan Ruang (UU Penataan Ruang) yang wewenang pelaksananya dimiliki oleh pemerintah pusat dan daerah dengan tetap menghormati hak setiap orang yang memilikinya.

Sebagai bentuk penataan ruang yang sesuai dengan kebutuhan masyarakat dilihat dari segi transportasi, maka yang menjadi permasalahan di Jakarta adalah semakin padatnya penduduk yang akhirnya berpengaruh dengan sistem transportasi yang padat pula. Maka seiring dengan perkembangan dalam bidang infrastruktur yang menunjukkan bahwa pemanfaatan suatu bidang tanah tidak hanya terbatas pada bidang tanah yang berupa permukaannya, ruang bawah tanah dapat dimanfaatkan sebagai bagian dari pembangunan dibidang transportasi. Kereta bawah tanah adalah penerapan yang tepat di Indonesia karena lahan di Indonesia sudah hampir tidak ada. Dalam hal ini, Pemerintah Daerah Khusus Ibu Kota Jakarta (DKI Jakarta) telah mengambil sebuah langkah untuk memanfaatkan ruang bawah tanah sebagai pembangunan sistem transportasi umum masal yang dikenal sebagai Mass Rapid Transit (MRT).

Seperti yang dikemukanan oleh Harris Sibuea, setiap badan usaha yang akan memanfaatkan ruang bawah tanah terlebih dahulu harus mendapatkan izin pemanfaatan ruang bawah tanah. Izin pemanfaatan ruang bawah tanah diberikan untuk dapat memanfaatkan ruang bawah tanah dengan batas dan luas tertentu sebagai pengendalian pemanfaatan ruang bawah tanah. Pemerintah daerah yang dimaksud adalah gubernur dan perangkat daerah sebagai unsur penyelenggara pemerintahan daerah. Sampai saat ini, yang dapat dijadikan sebagai dasar dari perizinan penguasaan bidang tanah beserta ruang di bawahnya untuk pelaksanaan pembangunan untuk proyek MRT ialah Peraturan Gubernur Provinsi Daerah Khusus Ibukota Jakarta Nomor 104 Tahun 2005 dan Peraturan Gubernur Provinsi Daerah Khusus Ibukota Jakarta Nomor 18 Tahun 2008 tentang Penguasaan Perencanaan/Peruntukan Bidang Tanah Untuk Pelaksanaan Pembangunan Bagi Kepentingan Umum Trase Jalur Mass Rapid, juga Peraturan Gubernur DKI Jakarta Nomor 167 Tahun 2012 tentang Ruang Bawah Tanah.

Berbagai permasalahan pemanfaatan ruang bawah tanah yang belum ada dasar haknya menurut peraturan perundang-undangan terkait penggunaan ruang bawah tanah akan memunculkan permasalahan. Hal ini disebabkan karena kewenangan negara yang disebut hak menguasai negara atas tanah akan sangat berkaitan dengan 
dasar hak bagi masyarakat yang memanfaatkan dan menggunakan ruang bawah tanah. . Oleh karena itu, perlu dilakukan analisis kesesuaian pemberian izin yang diberikan oleh Gubernur DKI Jakarta dengan peraturan perundang-undangan yang berkaitan dengan ruang bawah tanah dan sistem transportasi yaitu Peraturan Menteri Agraria dan Tata Ruang/Kepala Badan Pertanahan Nasional (BPN) Nomor 5 Tahun 2015 tentang Izin Lokasi, Peraturan Menteri Nomor 11 Tahun 2012 tentang Tata Cara Penerapan Trase Jalur Kereta Api, dan juga Peraturan Menteri Pekerjaan Umum Republik Indonesia Nomor 02/PRT/M/2014 tentang Pedoman Pemanfaatan Ruang di dalam Bumi. Dikarenakan masih minimnya peraturan dan pembahasan yang pasti mengenai kewenangan pemberian izin penggunaan dan pengelolaan ruang bawah tanah yang akan menimbulkan masalah terutama dalam pembangunan proyek MRT ini karena terdapat banyak aspek dan pihak yang terlibat terkait perizinan pemanfaatan ruang bawah tanah sebagai bagian dari pembangunan transportasi bawah tanah yang akan memecahkan masalah di DKI Jakarta.

Terkait dengan permasalahan tersebut, pembahasan dalam artikel ini akan dibagi menjadi dua bagian. Pertama, analisis mengenai mekanisme pemberian izin penggunaan ruang bawah tanah oleh PT. MRT Jakarta untuk pembangunan sistem transportasi umum massal. Kedua, kesesuaian izin yang telah diberikan tersebut kepada PT MRT Jakarta dengan peraturan perundang-undangan yang terkait. Keseluruhan topik tersebutlah yang akan menjadi pedoman alur analisis atau pokok bahasan.

\section{MEKANISME PERIZINAN PENGGUNAAN RUANG BAWAH TANAH OLEH PT MRT JAKARTA}

Yang termasuk dalam ruang lingkup agraria telah dijelaskan dalam Undang-Undang Pokok Agraria (UUPA) yaitu hal-hal yang berhubungan dengan bidang pertanahan meliputi bumi, air, ruang angkasa dan kekayaan alam yang terkandung di dalamnya. Dalam hal ruang lingkup bumi, yang termasuk di dalamnya ialah permukaan bumi (tanah), tubuh bumi, dan ruang yang ada di bawah permukaan air. Jika dilihat dalam aspek yuridisnya, tanah merupakan bagian dari agraria dan hak penguasaan atas tanah adalah hal yang melekat terhadap tanah. Dalam hak penguasaan atas tanah terdapat sebuah bentuk kewenangan, kewajiban, dan/atau larangan untuk yang memegang hak tersebut dalam hal berbuat sesuatu mengenai tanah yang menjadi haknya. Hak menguasai negara atas tanah bersumber dari hak bangsa Indonesia atas tanah yang hakikatnya merupakan penugasan pelaksanaan tugas kewenangan bangsa. Sebagaimana dalam Pasal 2 ayat (2) UUPA, wewenang hak negara menguasai atas tanah yaitu mengatur dan menyelenggarakan peruntukan, penggunaan, persediaan, dan pemeliharaan bumi, air, dan ruang angkasa. Pasal tersebut juga menentukan dan mengatur hubungan-hubungan hukum antara orang-orang dengan bumi, air, dan ruang

Harris Sibuea, "Tinjauan Yuridis atas Pemanfaatan Ruang Di Bawah Tanah", (2013), Jurnal Negara Hukum: Vol. 4 No. 1 , at 20. 
angkasa, serta menentukan dan mengatur hubungan-hubungan hukum yang mengenai bumi, air, dan ruang angkasa.

Pengertian dari hak menguasai negara atas tanah menurut Pasal 33 UUD 1945 dapat berupa kewenangan dalam hal pelaksanaannya sebagian dapat dilimpahkan atau diberikan kepercayaannya dalam mengelola kepada pemegang haknya untuk membentuk suatu rencana bagi peruntukan dan penggunaan tanah, menggunakan tanah untuk disesuaikan dengan keperluan pelaksanaan tugasnya, menyerahkan beberapa bagian-bagian tanah tersebut kepada yang disebut dengan pihak ketiga dan/atau dapat melaksanakan sebuah bekerja sama dengan pihak ketiga.

Dalam implementasinya, muncul Permen Agraria No. 9/1999 yang dalam pasal 67 menjelaskan bahwa hak pengelolaan dapat diberikan kepada instansi pemerintah termasuk pemerintah daerah, Badan Usaha Milik Negara (BUMN), Badan Usaha Milik Daerah (BUMD), PT Persero, badan hukum pemerintah lainnya yang ditunjuk oleh pemerintah, atau badan lain yang diberi pelimpahan kewenangan pelaksanaan sebagian hak menguasai dari negara atas tanah. Berdasarkan subjek hukum yang dapat diberi kewenangan pelaksanaan hak menguasai atas tanah negara yang telah dijelaskan dalam peraturan menteri tersebut. Dengan demikian, pelaksanaan hak menguasai atas tanah dapat diberikan kuasanya kepada pemerintah daerah ${ }^{2}$.

Sebagai salah satu pemerintah daerah yang mendapatkan kewenangan dari pemerintah pusat terkait hak pengelolaan atas tanah, Pemerintah Provinsi (Pemprov) DKI Jakarta mempunyai wewenang untuk mengelola kepentingan daerahnya yang berhubungan dengan pemanfaatan lahan atau tanah yang ada di wilayahnya ${ }^{3}$. Pemprov DKI Jakarta mendapat pelimpahan wewenang dalam pelaksanaan otonomi daerah atas hak menguasai tanah oleh negara berdasarkan kewenangan urusan pemerintahan konkuren yang diserahkan kepada daerah ${ }^{4}$. Pasal 6 Undang - Undang Nomor 29 Tahun 2007 tentang Pemprov DKI Jakarta sebagai Ibukota Negara Kesatuan Republik Indonesia bahwa bentuk penyelenggaraan Pemprov DKI Jakarta dilaksanakan menurut asas otonomi, asas dekonsentrasi, asas tugas pembantuan, dan kekhususan sebagai Ibukota Indonesia. Sebagai lembaga yang memiliki hak otonomi dalam menetapkan kebijakan dalam pelaksanaan urusan pemerintahannya, Pemerintah Daerah Provinsi DKI Jakarta menggunakan teori sumber kewenangan secara atribusi atau secara delegasi. Ini didasari pertimbangan bahwa kedudukan pemerintah daerah bukan sebagai bawahan dari pemerintah pusat, melainkan sebagai sub bagiannya ${ }^{5}$. Sesuai dengan ketentuan Permen Agraria No. 9/1999, maka Pemprov DKI Jakarta dalam hal pelaksanaan hak otonominya memiliki kewenangan untuk mengelola wilayah

\footnotetext{
Sulasi Rongiyati, "Pemanfaatan Hak Pengelolaan Atas Tanah Oleh Pihak Ketiga", (2014) Jurnal Negara Hukum: Vol. 5 No. 1, at 78.

3 Muhammad Bakri, Hak Menguasai Tanah oleh Negara: Paradigma Baru untuk Reformasi Agraria, (Jakaarta: Citra Media, 2007), at 37.

4 Bambang Rudito Kharisma, Aparatur Sipil Negara, (Jakarta: Prenada Media, 2016), at 90.

5 Suriansyah Murhaini, Budi Siswanto, Kewenangan Pemerintah Daerah Mengurus Bidang Pertanahan, (Universitas Michigan: LaksBang Justitia, 2009), at 85.
} 
daerahnya dengan membuat ketetapan dan pelaksanaan kebijakan dalam bidang tata ruang wilayahnya.

Jakarta adalah Ibukota Indonesia yang sampai saat ini bermasalah dengan kepadatan penduduk yang berpengaruh pada sistem transportasi yang padat pula. Pertumbuhan kendaraan di Jakarta per tahunnya sekitar 12\% dengan lebih dari 1000 kendaraan bermotor baru setiap harinya yang akan memberikan efek keadaan macet total yang diprediksi terjadi pada sekitar tahun 2020 dengan kerugian Rp 65 triliun per tahunnya ${ }^{6}$. Ini menjadi suatu permasalahan kesejahteraan masyarakat yang harus diselesaikan oleh Pemprov DKI Jakarta sebagai pelaksanaan amanat dari negara dalam hal pengelolaan otonomi daerahnya.

Adapun solusi permasalahan tersebut, Pemprov DKI Jakarta dengan kewenangan otonominya membentuk PT MRT Jakarta yang merupakan BUMD. Dibentuk pada 17 Juni 2008 sejak disahkannya Peraturan Daerah DKI Jakarta Nomor 3 Tahun 2008 tentang Pembentukan Badan Usaha Milik Daerah (Perda BUMD) PT MRT Jakarta. Dasar dibentuknya PT MRT ini dikarenakan pembangunan perkeretaapian perkotaan di Provinsi DKI Jakarta merupakan salah satu program prioritas nasional sesuai dengan kebijakan Pola Transportasi Makro dan sudah dituangkan dalam kesepakatan pembiayaan antara pemerintah pusat dan pemerintah daerah.

Dalam hal pengadaan lahan dan tanah milik pemerintah daerah yang dibutuhkan untuk keperluan pembangunan MRT Jakarta dilaksanakan oleh Pemerintah Daerah Provinsi DKI Jakarta. Dalam pemenuhan pengadaan kebutuhan lahan dan tanah yaitu dengan ditetapkannya Peraturan Gubernur Provinsi DKI Jakarta Nomor 104 Tahun 2005 tentang Penguasaan Perencanaan / Peruntukan Bidang Tanah Untuk Pelaksanaan Pembangunan Trase Jalur MRT Koridor Lebak Bulus - Kampung Bandan, Kotamadya Jakarta Selatan, Kotamadya Jakarta Pusat, Kotamadya Jakarta Barat dan Kotamadya Jakarta Utara dan juga Peraturan Gubernur Provinsi DKI Jakarta Nomor 18 Tahun 2008 tentang Penguasaan Perencanaan/Peruntukan Bidang Tanah Untuk Pelaksanaan Pembangunan Bagi Kepentingan Umum Trase Jalur MRT Koridor Lebak Bulus Dukuh Atas Kota Administrasi Jakarta Selatan. Dengan adanya peraturan tersebut, maka dapat disimpulkan bahwa Pemprov DKI Jakarta telah memberikan hak penggunaan tanah secara tertulis kepada PT MRT Jakarta dalam bentuk hak pengelolaan. Artinya hak penguasaan atas tanah penguasaan atas tanah negara dengan maksud untuk digunakan sendiri oleh pemegang haknya dapat memberikan suatu hak kepada pihak ketiga dengan wewenang untuk merencanakan peruntukan dan penggunaan hak atas tanah tersebut, menggunakan tanah tersebut untuk keperluan pelaksanaan tugasnya, dan menyerahkan bagian tanah tersebut untuk pihak ketiga dengan Hak Milik, Hak Guna Usaha, Hak Guna Bangunan, dan Hak Pakai yang pemberian hak atas bagian tanah tersebut dilakukan oleh pejabat yang berwenang ${ }^{7}$.

6 Heru Nugroho, "Proyek Pembangunan MRT Jakarta" (2015), presented at Seminar Pengenalan dan Dasar Teknik Terowongan, Direktorat Jembatan - Kementrian PU-Pera Republik Indonesia, Jakarta

7 Ali Ahmad Chomzah, Hukum Pertanahan Seri Hukum Pertanahan I dan II, (Jakarta: Prestasi Pustaka, 2002), at 55 . 
Secara penggunaan lahan, MRT juga memanfaatkan ruang bawah tanah dari beberapa lahan yang dipergunakan untuk sarana dan prasarananya. Hal ini sebagai langkah penanggulangan terlalu padatnya permukaan tanah untuk dibuat jalur transportasi baru. Jalur ruang bawah tanah yang dimanfaatkan tertuang pada Tabel 6 Lampiran II Peraturan Daerah DKI Jakarta Nomor 1 Tahun 2012 tentang Rencana Tata Ruang Wilayah 2030 yang menyebutkan bahwa jalur tersebut membentang sepanjang 6 kilometer dengan variasi kedalaman 17,5 - 28 meter di bawah permukaan tanah. Di mana nantinya terdiri dari enam stasiun MRT yang terdiri dari Stasiun Senayan, Stasiun Istora, Stasiun Bendungan Hilir, Stasiun Setiabudi, Stasiun Dukuh Atas dan Stasiun Bundaran Hotel Indonesia. Pada tiap stasiunnya terdiri dari dua lantai yaitu concourse area sebagai area komersial dan platform area atau biasa disebut peron penumpang sebagai area menunggu kereta ${ }^{8}$. Dalam pemberian izin pemanfaatan ruang yang telah direncanakan dalam Perda tersebut, termasuk pula pemanfaatan ruang bawah tanah ditetapkan oleh pemerintah daerah melalui peraturan gubernur.

Dapat disimpulkan bahwa perizinan penggunaan ruang bawah tanah oleh PT MRT Jakarta yang diberikan oleh Pemprov DKI Jakarta untuk pembangunan sistem transportasi umum massal berupa sebuah bentuk dokumen legal tertuang dalam Peraturan Gubernur Provinsi DKI Jakarta Nomor 167 Tahun 2012 tentang Ruang Bawah Tanah telah sesuai karena kewenangan pengelolaan ruang bawah tanah dalam dikelola oleh pemerintah daerah. Hal ini juga berdasarkan asas otonomi daerah yang dijelaskan dalam Undang-Undang Nomor 23 Tahun 2014 tentang Pemerintah Daerah (UU Pemda). Dengan demikian, yang menjadi dasar kewenangan Gubernur DKI Jakarta dalam memberikan izin penggunaan ruang bawah tanah yang digunakan untuk MRT. Karena dalam pemanfaatan wilayah daerahnya menjadi kewenangan dari pemerintah daerah tersebut. Untuk pemberian izin penggunaan dan pemanfaatannya oleh pihak ketiga pun yang memberikan adalah dari pemerintah daerah sebagai bentuk pelimpahan sebagai usaha pemerintah dalam memberikan pelayanan dalam hal kesejahteraan masyarakatnya.

\section{KESESUAIAN PEMBERIAN IZIN PENGGUNAAN RUANG BAWAH TANAH OLEH PEMERINTAH PROVINSI DKI JAKARTA}

Izin yang dibuat oleh Gubernur DKI Jakarta melalui Peraturan Gubernur Nomor 167 Tahun 2012 tentang Ruang Bawah Tanah perlu dilakukan analisis kesesuaian dengan peraturan perundang-undangan yang terkait karena beberapa hal. Misalnya karena Jakarta termasuk kawasan strategis nasional maka butuh pengendalian secara terpadu oleh pemerintah pusat, disebabkan pula proyek MRT termasuk dalam Pola Pembangunan Nasional maka perlu adanya campur tangan serta pengawasan dari pemerintah pusat dalam pelaksanaannya, serta adanya peraturan perundang-undangan

8 PT MRT Jakarta, Konstruksi Jalur Layang dan Bawah Tanah Selintas Tentang Penyangga Utama MRT Jakarta Fase 1: Jakarta MRT online: https://www.jakartamrt.co.id/2017/06/01/konstruksi-jalur-layang-danbawah-tanah-selintas-tentang-penyangga-utama-mrt-jakarta-fase-1/ 
yang mengatur mengenai Ruang Bawah Tanah. Sedangkan Gubernur DKI Jakarta telah mengeluarkan Peraturan Gubernur terkait Ruang Bawah Tanah, maka harus disesuaikan peraturan tersebut dengan peraturan yang berkaitan.

Dalam kebijakan UU Penataan Ruang bahwa sejalan dengan kebijakan otonomi daerah yang memberikan kewenangan yang semakin besar kepada pemerintah daerah dalam penyelenggaraan penataan ruang. Hal ini sangat penting dilakukan mengingat keberadaan ruang yang terbatas, sehingga diperlukan penyelenggaraan penataan ruang yang transparan, efektif, dan partisipatif agar terwujudnya ruang yang aman, nyaman, produktif dan berkelanjutan. Oleh karena itu, kewenangan pemerintah daerah tersebut perlu diatur demi menjaga keserasian dan keterpaduan antardaerah dan antara pusat dan daerah agar tidak menimbulkan kesenjangan daerah.

Izin pemanfaatan ruang bawah tanah oleh Gubernur DKI Jakarta untuk MRT melalui Peraturan Gubernur Nomor 167 Tahun 2012 tentang Ruang Bawah Tanah disesuaikan dengan beberapa peraturan perundang - undangan yang berkaitan. Pertama, Peraturan Menteri Agraria dan Tata Ruang/Kepala Badan Pertanahan Nomor 5 Tahun 2015 tentang Izin Lokasi, dilihat dari sisi pemanfaatan ruang untuk kepentingan umum oleh suatu perusahaan yang berkaitan dengan penanaman modal dibutuhkan izin lokasi guna dilaksanakannya pembebasan/pelepasan hak atas tanah. Kedua, Peraturan Menteri Perhubungan Nomor 11 Tahun 2012 tentang Tata Cara Penetapan Trase Jalur Kereta Api karena dari bentuk transportasinya yaitu perkeretaapian, maka dibutuhkan penyesuaian dengan rencana jalur MRT dengan penggunaan jalur perkeretaapian oleh Menteri Perhubungan. Ketiga, Peraturan Menteri Pekerjaan Umum Nomor 02/PRT/M/2014 tentang Pedoman Pemanfaatan Ruang di dalam Bumi, karena dalam hal pemanfaatan ruang yang termasuk dalam kawasan strategis nasional dan pola pembangunan nasional ini menjadi tanggung jawab Menteri Pekerjaan Umum.

\section{A. Peraturan Menteri Agraria dan Tata Ruang/Kepala Badan Pertanahan Nasional Nomor 5 Tahun 2015 tentang Izin Lokasi}

Jika ditelusuri terkait keterlibatan negara yang bertindak sebagai pemilik tanah sesuai dengan Pasal 2 UUPA yang merupakan aturan pelaksanaan Pasal 33 ayat (3) UUD 1945, yang selanjutnya negara memberi wewenang kepada pihak yang terkait yaitu Menteri Agraria dan Tata Ruang/Kepala BPN dalam hal penyelenggaraan peruntukan, penggunaan, persediaan dan pemeliharaannya serta menentukan dan mengatur hakhak yang dapat dimiliki atas bagian dari bumi, air, dan ruang angkasa ${ }^{9}$. Dan dalam hal untuk memperoleh tanah untuk kepentingan penanaman modal diperlukan adanya suatu izin lokasi dari Menteri Agraria dan Tata Ruang/ Kepala BPN sebelum suatu perusahaan tersebut melakukan pembebasan atau pelepasan hak atas tanah dari masyarakat. Izin lokasi ini dapat diberikan berdasarkan pertimbangan mengenai aspek penguasaan tanah dan teknis tata guna yang meliputi keadaan hak serta penguasaan

9 Muhammad Bakri, Hak Menguasai Tanah oleh Negara (Paradigma Baru Untuk Reformasi Agraria), (Yogyakarta: Repository USU, 2007), at 4. 
tanah yang bersangkutan, penilaian fisik wilayah, penggunaan tanah, serta kemampuan tanah. Sebuah izin lokasi diterbitkan dalam bentuk Surat Keputusan yang ditandatangani oleh Bupati/ Walikota, khususnya untuk DKI Jakarta, oleh Gubernur DKI Jakarta setelah diadakan rapat koordinasi antar instansi terkait.

PT MRT Jakarta adalah sebuah BUMD berbentuk PT yang dibentuk oleh Pemprov DKI Jakarta berdasarkan Peraturan Daerah Provinsi DKI Jakarta Nomor 3 Tahun 2008 tentang BUMD PT MRT Jakarta. Menurut Hari Soedjojo, pemerintah daerah dapat menanamkan modalnya pada BUMD dan dapat melakukan penambahan, pengurangan penjualan kepada pihak lain, dan/atau dialihkan yang ditetapkan dengan peraturan daerah yang berpedoman pada peraturan perundang-undangan .

Maka dapat disimpulkan, jika dihubungkan dengan izin lokasi dalam hal pemanfaatan ruang bawah tanah oleh PT MRT Jakarta, harus disesuaikan dengan Peraturan Menteri Agraria dan Tata Ruang/ Kepala BPN Nomor 5 Tahun 2015 tentang Izin Lokasi. Yang mana PT MRT telah memegang izin lokasi dalam penggunaan ruang bawah tanah sesuai dengan peraturan yang telah di tetapkan Menteri Agraria dan Tata Ruang/ Kepala BPN. Dengan penjelasan peraturan terebut, dengan analisis bahwa izin lokasi tidak diperlukan dan dianggap sudah dimiliki oleh PT MRT. Dalam hal tanah yang akan diperoleh merupakan pemasukan (inbreng) dari Pemprov DKI Jakarta sebagai pemegang saham. Termasuk izin lokasi tidak diperlukan dan dianggap sudah dimiliki dalam hal tanah yang akan dipergunakan untuk melaksanakan rencana penanaman modal merupakan tanah yang sudah dipunyai oleh perusahaan yang bersangkutan melalui peralihan hak dengan ketentuan bahwa tanah tersebut terletak di lokasi yang menurut Rencana Tata Ruang Wilayah yang berlaku diperuntukkan bagi penggunaan yang sesuai dengan rencana penanaman modal yang bersangkutan.

\section{B. Peraturan Menteri Perhubungan Republik Indonesia Nomor 11 Tahun 2012 tentang Tata Cara}

\section{Penetapan Trase Jalur Kereta Api}

Perkeretaapian adalah satu kesatuan sistem yang terdiri atas prasarana, sarana, dan sumber daya manusia serta norma, kriteria, persyaratan dan prosedur untuk penyelenggaraan transportasi kereta api. Dalam implementasi Pasal 115 Peraturan Pemerintah Nomor 56 Tahun 2009 tentang Penyelenggaraan Perkeretaapian, maka dibuatlah Peraturan Menteri Perhubungan Nomor 11 Tahun 2012 tentang Tata Cara Penetapan Trase Jalur Kereta Api (Permenhub No 11 Tahun 2012). Penetapan ini bertujuan untuk mewujudkan keharmonisan antara jaringan jalur kereta api dan perencanaan tata ruang wilayah sesuai tatarannya. Keterpaduan pengendalian pemanfaatan ruang untuk jaringan jalur kereta api dalam rangka perlindungan fungsi ruang dan pencegahan dampak negatif terhadap lingkungan akibat pembangunan jalur kereta api. Keterpaduan jaringan jalur kereta api sebagai satu kesatuan sistem jaringan transportasi nasional, sehingga mempermudah dan memperlancar pelayanan angkutan orang dan/atau barang, serta efisiensi penyelenggaraan perkeretaapian. Penetapan jalur kereta api yang memuat titik koordinat, lokasi stasiun, rencana kebutuhan lahan dan skala gambar ini ditetapkan sesuai kewenangannya menteri, gubernur ataupun 
Bupati/Walikota sesuai rencana induk perkeretaapian dan di luar rencana induk perkeretaapian. Untuk gubernur maupun Bupati/Walikota dalam menetapkan trase jalur kereta api harus terlebih dahulu mendapat persetujuan menteri.

Atas dasar Permenhub No 11 Tahun 2012yang menjelaskan bahwa rencana induk perkeretaapian yang ditetapkan oleh gubernur harus dengan persetujuan menteri. Dengan demikian, Pemprov DKI Jakarta telah membuat Peraturan Daerah Provinsi DKI Jakarta Nomor 12 Tahun 2003 tentang Lalu Lintas dan Angkutan Jalan, Kereta Api, Sungai dan Danau Serta Penyeberangan di Provinsi DKI Jakarta. Dalam peraturan tersebut dijelaskan bahwa dengan mengacu pada Rencana Tata Ruang Wilayah Provinsi DKI Jakarta maka ditetapkan Rencana Umum Jaringan Transportasi Kota yang diwujudkan dalam Pola Transportasi Makro yang ditetapkan dengan keputusan gubernur.

Jadi dari analisis fakta - fakta yang ada, sesuai dengan Permenhub No ll Tahun 2012,maka perizinan penggunaan ruang bawah tanah yang dikeluarkan oleh Pemprov DKI Jakarta telah sesuai dengan Permenhub tersebut. Pemerintah Provinsi DKI Jakarta telah membuat rencana induk perkeretaapian yang tertuang dalam Rencana Tata Ruang Wilayah 2030 Provinsi DKI Jakarta yang menjelaskan bahwa sudah direncanakannya jaringan prasarana angkutan massal dengan koridor-koridor yang sudah ditentukan dan disetujui oleh Gubernur DKI Jakarta yang menjabat pada saat itu yaitu Fauzi Bowo. Pada Lampiran I Peraturan Daerah Provinsi DKI Jakarta Nomor 1 Tahun 2012 tentang Rencana Tata Ruang Wilayah 2030 terkait penggunaan ruang di bawah permukaan tanah di daerah-daerah yang digunakan untuk trase jalur kereta api dengan sistem MRT. Maka keputusan yang dibuat oleh Gubernur DKI Jakarta telah sesuai dengan Permenhub terkait trase jalur perkeretaapian bawah tanah yang dimanfaatkan oleh PT MRT Jakarta.

\section{Peraturan Menteri Pekerjaan Umum Republik Indonesia Nomor 02/PRT/M/2014 tentang Pedoman Pemanfaatan Ruang di Dalam Bumi}

Sesuai dengan Undang - Undang Nomor 26 Tahun 2007 tentang Penataan Ruang, bahwa wewenang pemerintah dalam penyelenggaraan penataan ruang meliputi ${ }^{10}$ pengaturan, pembinaan, dan pengawasan terhadap pelaksanaan penataan ruang wilayah nasional, provinsi, dan kabupaten/kota. Adapun wewenang lainnya seperti terhadap pelaksanaan penataan ruang kawasan strategis nasional, provnsi, dan kabupaten/kota, kemudian pelaksanaan penataan ruang wilayah nasional, juga pelaksanaan penataan ruang kawasan strategis nasional, serta kerja sama penataan ruang antar negara dan pemfasilitasan kerja sama penataan ruang antar provinsi.

Berdasarkan penjelasan di atas, maka negara memberikan wewenang kepada menteri dalam hal penyelenggaraan penataan ruang dengan tugas dan tanggung jawab diantaranya untuk pengaturan, pembinaan dan pengawasan penataan ruang; pelaksanaan penataan ruang nasional; dan koordinasi penyelenggaraan penataan ruang lintas sektor, lintas wilayah, dan lintas pemangku kepentingan. Menteri yang

10 Lihat Pasal 8 ayat (1) Undang - Undang Nomor 26 Tahun 2007 tentang Penataan Ruang 
memegang peran ini adalah Menteri Pekerjaan Umum dan Perumahan Rakyat (PUPR), berdasarkan tugas menyelenggarakan urusan pemerintah di bidang pekerjaan umum dan perumahan rakyat untuk membantu presiden dalam menyelenggarakan pemerintahan negara.

Dalam hal ini, Menteri PUPR bertanggung jawab atas penataan ruang yang termasuk kawasan strategis nasional dalam rangka mengatasi keterbatasan lahan di permukaan bumi, mewujudkan keterpaduan antar kegiatan, serta menjaga dan meningkatkan kualitas ruang dan kelestarian lingkungan yang diperlukan untuk optimalisasi pemanfaatan ruang di dalam bumi. Sehingga diterbitkanlah Peraturan Menteri Pekerjaan Umum Nomor 02/PRT/M/2014 tentang Pedoman Pemanfaatan Ruang di Dalam Bumi. Peraturan Menteri ini dimaksudkan sebagai acuan bagi pemerintah, Pemprov, dan pemerintah Kabupaten/Kota, serta pemangku kepentingan lainnya dalam menyelenggarakan pemanfaatan ruang dalam bumi sesuai dengan kaidah penataan ruang. Hal ini dimaksudkan untuk mendukung pembangunan yang efisien dan efektif sehingga dapat mewujudkan ruang yang aman, nyaman, produktif, dan berkelanjutan. Izin pemanfaatan ruang bawah tanah ini bertujuan untuk mengatur pemanfaatan uang bawah tanah, mengatur fungsi bangunan yang dapat dibangun, mengatur ketinggian maksimum bangunan yang diizinkan, mengatur jumlah lantai/lapis bangunan di bawah tanah yang diizinkan, dan mengendalikan lingkungan, geologi/kondisi bawah tanah dan air tanah.

Pemanfaatan ruang dalam bumi berdasarkan Peraturan Menteri Pekerjaan Umum Nomor 02/PRT/M/2014 terkait Pedoman Pemanfaatan Ruang di Dalam Bumi memiliki beberapa ketentuan teknis yang telah diatur. Salah satunya adalah ketentuan kedalaman pemanfaatan ruang dalam bumi. Pembagian kedalaman pemanfaatan ruang dalam bumi ini menjadi acuan dalam penetapan jenis kegiatan yang diprioritaskan dan penetapan letaknya di bawah ruang publik atau di bawah ruang privat. Kedalaman pemanfaatan ruang dalam bumi ini disesuaikan dengan karakteristik fisik dan/atau kondisi geologi masing-masing wilayah. Secara umum, kedalaman pemanfaatan ruang dalam bumi ini terbagi atas beberapa kriteria.

Pertama, Ruang Dalam Bumi dangkal yang berada pada kedalaman 0 (nol) sampai dengan 30 meter di bawah permukaan tanah yang diprioritaskan untuk kegiatan yang letaknya berdekatan atau menyatu dengan ruang atau kegiatan di permukaan, kegiatan yang membutuhkan akses dari dan ke ruang dalam bumi dangkal, kegiatan yang sumber dayanya terletak di ruang dalam bumi dangkal, dan kegiatan yang berdasarkan hasil studi atau alasan tertentu dapat di tempatkan pada ruang ini atau bahkan sebaliknya.

Kedua, Ruang Dalam Bumi dalam yang berada pada kedalaman lebih dari 30 meter di bawah permukaan tanah yang diprioritaskan untuk kegiatan yang menghubungkan antar pusat kegiatan, antarwilayah, dan jaringan utama, kegiatan yang membutuhkan tingkat keamanan tinggi, kegiatan yang sumber dayanya terletak di ruang dalam bumi dalam, dan kegiatan yang berdasarkan hasil studi atau alasan tertentu dapat ditempatkan pada ruang ini atau bahkan sebaliknya. 
Terkait kedalaman ini juga telah diatur dan terdapat dua hal yang menyangkut kewenangan mengelola bangunan yang berada di ruang bawah tanah menurut Peraturan Gubernur DKI Jakarta Nomor 167 Tahun 2012 tentang Ruang Bawah Tanah. Kewenangan mengelola bangunan di ruang bawah tanah dangkal di mana selalu mengikuti akan proses bangunan yang berada di atas tanah, sehingga kegiatan pembangunan di ruang bawah tanah dilakukan masih melekat dengan bangunan yang di atas tanah. Keberadaan proses pembangunan ini hanya dari permukaan tanah sampai dengan kedalaman 10 M. Di sini merupakan kewenangan bagi rumah-rumah pribadi untuk memperbesar ruangan rumahnya. Kegiatan yang diperbolehkan pada ruang bawah tanah dangkal antara lain akses stasiun MRT, yaitu angkutan massal yang berbasis pada jalan rel yang memanfaatkan jalur-jalur khusus, sistem jaringan prasarana jalan, sistem jaringan utilitas, kawasan perkantoran, fasilitas parkir, perdagangan dan jasa, pendukung kegiatan gedung di atasnya dan pondasi bangunan di atasnya. Sedangkan kewenangan mengelola bangunan yang berada di ruang bawah tanah dalam ini mempunyai batas dari permukaan tanah sampai kedalaman $40 \mathrm{M}$ dan sampai kemampuan teknologi. Hal ini hanya dilakukan oleh pemerintah demi menjamin akan kesejahteraan masyarakat dengan melihat akan apa yang menjadi kebutuhan masyarakat di setiap daerah. Kegiatan yang diperbolehkan pada Ruang Bawah Tanah Dalam diantaranya sistem MRT, (sistem jaringan prasarana jalan, sistem jaringan utilitas dan pondasi bangunan gedung di atasnya.

Dalam hal ini, terdapat perbedaan terkait kriteria kedalaman ruang dalam bumi antara Peraturan Menteri Pekerjaan Umum Nomor 02/PRT/M/2014 tentang Pedoman Pemanfaatan Ruang di Dalam Bumi dengan Peraturan Gubernur DKI Jakarta Nomor 167 Tahun 2012 tentang Ruang Bawah Tanah. Padahal dalam hierarki perundangundangan menurut Widodo Ekatjahjana, penjenjangan setiap jenis peraturan perundang-undangan yang didasarkan pada asas bahwa peraturan perundangundangan yang lebih rendah tidak boleh bertentangan dengan peraturan perundangundangan yang lebih tinggi ${ }^{11}$. Sebelumnya harus dipahami dulu kedudukan Peraturan Menteri di dalam hierarki perundang-undangan. Menurut Hamid Attamimmi, hanya dikenal dua macam peraturan perundang-undangan dilihat dari dasar kewenangan pembentukannya, yaitu peraturan perundang-undangan yang dibentuk atas dasar atribusi dan delegasi. Kewenangan atribusi diartikan penciptaan wewenang oleh konstitusi atau oleh pembentuk undang-undang yang diberikan kepada suatu organ negara, baik yang sudah ada maupun yang dibentuk baru untuk itu ${ }^{12}$. Sementara itu, delegasi dalam bidang perundang-undangan ialah pemindahan/penyerahan kewenangan untuk membentuk peraturan dari pemegang kewenangan asal yang mendelegasikan kepada yang menerima dengan tanggung jawab pelaksanaan

11 Widodo Ekatjahjana, Pembentukan Peraturan Perundang - Undangan : Dasar - Dasar dan Teknik Penyusunannya, (Jakarta: Citra Aditya Bakti, 2008), at 57.

12 Hamid S. Attamimmi, Peranan Keputusan Presiden Republik Indonesia dalam Penyelenggaraan Pemerintah Negara : Studi Analisis Keputusan Presiden yang Berfungsi Pengaturan dalam Kurun Waktu Pelita I - Pelita VI, (Jakarta: Disertasi, Fakultas Pasca Sarjana Universitas Indonesia, 1990), at 352. 
kewenangan tersebut pada yang menerima delegasi sendiri. Sedangkan tanggung jawab pemberi delegasi terbatas sekali. ${ }^{13}$

Peraturan Daerah Provinsi DKI Jakarta Nomor 167 Tahun 2012 tentang Ruang Bawah Tanah tidak perlu dicabut hanya karena terdapat perbedaan dengan peraturan di atasnya yaitu Peraturan Menteri Pekerjaan Umum Nomor 02/PRT/M/2014 tentang Pedoman Pemanfaatan Ruang di Dalam Bumi karena peraturan daerah yang seperti itu tidak perlu dicabut, meskipun terdapat perbedaan dengan peraturan perundangundangan yang lebih tinggi. Akan tetapi Peraturan Daerah Provinsi DKI Jakarta Nomor 167 Tahun 2012 tentang Ruang Bawah Tanah tersebut menjadi aspirasi daerah dan lebih dahulu muncul sebelum Menteri PUPR menetapkan Peraturan Menteri Pekerjaan Umum Nomor 02/PRT/M/2014 tentang Pedoman Pemanfaatan Ruang di Dalam Bumi. Walaupun Peraturan Menteri ini dibentuk untuk menjadi pedoman bagi pemerintah daerah, tetapi pemerintah daerah telah menentukan sendiri pedoman pemanfaatan ruang bawah tanahnya sesuai asas otonomi daerah. Maka Peraturan Daerah Provinsi DKI Jakarta Nomor 167 Tahun 2012 tentang Ruang Bawah Tanah tidak dapat dianggap menyalahi Peraturan Menteri Pekerjaan Umum Nomor 02/PRT/M/2014 tentang Pedoman Pemanfaatan Ruang di Dalam Bumi walaupun terdapat perbedaan dalam penentuan kriteria kedalaman ruang dalam bumi yang dapat dimanfaatkan.

Berdasarkan adanya penjelasan dari perbedaan tersebut dan dengan adanya fleksibilitas dari Peraturan Menteri Pekerjaan Umum, menurut hasil analisis, maka izin pemanfaatan ruang bawah tanah untuk PT MRT ini dapat diberikan secara khusus oleh gubernur berdasarkan rekomendasi dari Kepala Satuan Kerja Perangkat Daerah terkait dan sebagai pendukungnya juga mendapat persetujuan dari Menteri PUPR dalam hal pemanfaatan ruang dalam bumi. Juga terdapat wujud dukungan Menteri PUPR terkait pemanfaatan ruang dalam bumi dalam proyek MRT ini dengan tercantumnya dalam Lampiran Peraturan Menteri Pekerjaan Umum Nomor 02/PRT/M/2014 tentang Pedoman Pemanfaatan Ruang di Dalam Bumi bahwa jaringan transportasi wilayah seperti MRT termasuk dalam klasifikasi pemanfaatan ruang dalam bumi menurut jenis fasilitas sistem jaringan prasarana dan juga pemanfaatan menurut skala pelayanan. Adapun kaidah umum pemanfaatan ruang dalam bumi telah dijelaskan bahwa pengelolaan ruang dalam bumi untuk kepentingan publik dapat dilaksanakan oleh pemerintah daerah.

\section{KESIMPULAN}

Mekanisme perizinan penggunaan ruang bawah tanah oleh PT MRT Jakarta untuk pembangunan sistem transportasi umum masal yang diberikan oleh Pemprov DKI Jakarta sudah tepat sesuai dengan regulasi yang tertuang dalam prinsip pelaksanaan otonomi daerah. sebagaimana Pasal 9 Undang-Undang Nomor 23 Tahun 2014 tentang Pemerintah Daerah, pemerintah daerah diberi kewenangan untuk mengatur dan memanfaatkan wilayahnya, tetapi mengingat hingga saat ini masih minimnya regulasi

13 Ibid at 347. 
dari pemerintah pusat mengenai pemanfaatan ruang bawah tanah apalagi diperuntukkan demi kepentingan umum. Hal ini nantinya akan menimbulkan persoalan terhadap penerapannya. Perlu adanya landasan hukum yang tepat dari peraturan perundang-undangan yang berkaitan dengan pemanfaatan ruang bawah tanah dikarenakan pembahasan ini akan meluas ke permasalahan terkait hak guna ruang bawah tanah yang hingga saat ini belum ada peraturan perundang-undangan yang mengatur tentang hal tersebut.

Kemudian dikarenakan belum adanya peraturan perundang-undangan yang membahas pemanfaatan ruang bawah tanah, maka pemberian izin untuk MRT ini harus disesuaikan dengan peraturan perundang-undangan. Setidaknya berkaitan dengan hal tersebut agar tidak ada tumpang tindih regulasi dan adanya keserasian antara regulasi yang dibuat oleh pemerintah daerah dengan pemerintah pusat. Pemberian izin oleh Gubernur DKI Jakarta memunculkan ketidaksesuai dengan beberapa peraturan yang dibuat oleh pemerintah pusat. Akan tetapi, peraturan utama yang dipergunakan dalam pemanfaatan ruang bawah tanah untuk proyek MRT di wilayah DKI Jakarta ini tetap menggunakan Peraturan Gubernur Nomor 167 Tahun 2012 tentang Ruang Bawah Tanah.

Untuk menyesuaikan dan menegaskan perizinan yang telah dikeluarkan oleh Gubernur DKI Jakarta terkait penggunaan ruang bawah tanah untuk MRT di Jakarta dengan beberapa peraturan perundang-undangan yang diterbitkan oleh pemerintah pusat yang terkait diatas, maka Gubernur DKI Jakarta membuat Peraturan Gubernur Provinsi DKI Jakarta Nomor 53 Tahun 2017 tentang Penugasan kepada PT Mass Rapid Transit Jakarta untuk penyelenggaraan prasarana dan sarana MRT. Dalam peraturan tersebut dijelaskan beberapa pasal yang mengakomodir kesesuaiannya dengan peraturan yang ditetapkan oleh Menteri Agraria dan Tata Ruang/ Kepala BPN terkait izin lokasi, lalu Menteri Perhubungan terkait penetapan trase jalur perkeretaapian, serta Menteri PUPR tentang pedoman penggunaan ruang dalam bumi.

Oleh karena itu, untuk mewujudkan kepastian hukum, perlu segera disahkannya Rancangan Undang-Undang Pertanahan yang bertujuan untuk membahas lebih rinci terkait pemanfaatan ruang bawah tanah oleh pihak-pihak yang akan memanfaatkannya. Hal ini dilakukan guna ada kepastian hukum yang menjadi dasar pemanfaatan ruang bawah tanah karena permasalahan pemanfaatan ruang bawah tanah ini nantinya akan meluas ke pembahasan hak guna atas ruang bawah tanah. Dengan demikian, perlu segera dirumuskan terkait ketentuan-ketentuannya agar terwujud kepastian hukum terhadap kepemilikan dari ruang bawah tanah. Perlu juga adanya keselarasan pengaturan terhadap peraturan perundang-undangan dan pengawasan dari pemerintah pusat dalam pelaksanaan otonomi daerah yang dilaksanakan oleh pemerintah daerah agar tidak adanya tumpang tindih peraturan perundang - undangan yang berlaku. Terlebih lagi agar tetap sesuai dengan mekanisme yang berlaku dalam sistem perundang-undangan dalam hal pembuatan kebijakan agar tidak menyalahi hierarki peraturan perundang-undangan di Indonesia. 


\section{DAFTAR PUSTAKA}

Ali Ahmad Chomzah, Hukum Pertanahan Seri Hukum Pertanahan I dan II, (Jakarta: Prestasi Pustaka, 2002).

Bambang Rudito Kharisma, Aparatur Sipil Negara, (Jakarta: Prenada Media, 2016).

Hamid S. Attamimmi, "Peranan Keputusan Presiden Republik Indonesia dalam Penyelenggaraan Pemerintah Negara: Studi Analisis Keputusan Presiden yang Berfungsi Pengaturan dalam Kurun Waktu Pelita I - Pelita VI", (1990) Disertasi, Fakultas Pasca Sarjana Universitas Indonesia.

Heru Nugroho, "Proyek Pembangunan MRT Jakarta", (2015) Seminar Pengenalan dan Dasar Teknik Terowongan, Direktorat Jembatan - Kementrian PU-Pera Republik Indonesia, Jakarta.

Muhammad Bakri, Hak Menguasai Tanah Oleh Negara: Paradigma Baru Untuk Reformasi Agraria, (Jakarta: PT Elex Media Komputindo,2007)

Peraturan Presiden Republik Indonesia Nomor 54 Tahun 2008 tentang Penataan Ruang Kawasan Jakarta, Bogor, Depok, Tangerang, Bekasi, Puncak, Cianjur.

Peraturan Pemerintah Nomor 25 Tahun 2000 Tentang Kewenangan Pemerintah dan Kewenangan Propinsi Sebagai Otonom, Lembaran Negara Republik Indonesia Tahun 2000 Nomor 54.

Peraturan Menteri Dalam Negeri Nomor 1 Tahun 1977 tentang Tata Cara Permohonan dan Penyelesaian Pemberian Hak Atas Bagian-Bagian Tanah Hak Pengelolaan Serta Pendaftarannya.

Peraturan Menteri Dalam Negeri Nomor 20 Tahun 2008 tentang Pedoman Organisasi dan Tata Kerja Unit Pelayanan Perizinan Terpadu di Daerah.

Peraturan Menteri Perhubungan Nomor 11 Tahun 2012 tentang Tata Cara Penetapan Trase Jalur Kereta Api

Peraturan Menteri Pekerjaan Umum Nomor 02/PRT/M/2014 tentang Pedoman Pemanfaatan Ruang di Dalam Bumi

Peraturan Menteri Agraria dan Tata Ruang/ Kepala Badan Pertanahan Nasional Nomor 5 Tahun 2015 tentang Izin Lokasi, Berita Negara Republik Indonesia 2015 Nomor 647.

Peraturan Gubernur Provinsi DKI Jakarta Nomor 167 Tahun 2012 Tentang Ruang Bawah Tanah, Berita Daerah Provinsi Daerah Khusus Ibukota Jakaarta Tahun 2012 Nomor 162.

Peraturan Gubernur Provinsi Daerah Khusus Ibukota Jakarta Nomor 53 Tahun 2017 Tentang Penugasan Kepada Perseroan Terbatas MRT Jakarta untuk Penyelenggaraan Prasarana dan Sarana Mass Rapid Transit, Berita Daerah Provinsi Daerah Khusus Ibukota Jakarta Tahun 2017 Nomor 23005.

Peraturan Daerah Provinsi DKI Jakarta Nomor 3 Tahun 2008 tentang Pembentukan Badan Usaha Milik Daerah (BUMD) Perseroan Terbatas (PT) MRT Jakarta, Lembaran Daerah Provinsi DKI Jakarta Tahun 2008 Nomor 3. 
Peraturan Daerah Provinsi DKI Jakarta Nomor 4 Tahun 2008 tentang Penyertaan Modal Daerah Pada Perseroan Terbatas (PT) Mass Rapid Transit Jakarta, Lembaran Daerah Provinsi Khusus Ibukota Jakarta Tahun 2008 Nomor 4.

Peraturan Daerah Provinsi DKI Jakarta Nomor 1 Tahun 2012 tentang Rencana Tata Ruang Wilayah 2030

Peraturan Daerah Provinsi DKI Jakarta Nomor 7 Tahun 2013 Tentang Perubahan Atas Peraturan Daerah Nomor 3 Tahun 2008 Tentang Pembentukan Badan Usaha Milik Daerah (BUMD) Perseroan Terbatas (PT) MRT Jakarta, Lembaran Daerah Provinsi Daerah Khusus Ibukota Jakarta Tahun 2013 Nomor 104, Tambahan Lembaran Daerah Provinsi Daerah Khusus Ibukota Jakarta Nomor 1002.

Sulasi Rongiyati, "Pemanfaatan Hak Pengelolaan Atas Tanah Oleh Pihak Ketiga", (2014) Negara Hukum: Vol. 5 No. 1.

Suriansyah Murhaini, Budi Siswanto, Kewenangan Pemerintah Daerah Mengurus Bidang Pertanahan, (Universitas Michigan: LaksBang Justitia, 2007).

Undang - Undang Dasar Negara Republik Indonesia Tahun 1945.

Undang - Undang Nomor 5 Tahun 1960 Tentang Peraturan Dasar Pokok - Pokok Agraria, Lembaran Negara Republik Indonesia Tahun 1960 Nomor 104, Tambahan Lembaran Negara Nomor 2043.

Undang - Undang Nomor 26 Tahun 2007 Tentang Penataan Ruang, Lembar Negara Republik Indonesia Tahun 2007 Nomor 68, Tambahan Lembaran Negara Nomor 4725 .

Undang-Undang Nomor 29 Tahun 2007 tentang Pemerintah Provinsi Daerah Khusus Ibu Kota Jakarta Sebagai Ibukota Negara Kesatuan Republik Indonesia, Lembaran Negara Republik Indonesia Tahun 2007 Nomor 93, Tambahan Lembaran negara Nomor 4744.

Widodo Ekatjahjana, Pembentukan Peraturan Perundang - Undangan : Dasar - Dasar dan Teknik Penyusunannya, (Jakarta: Citra Aditya Bakti, 2008). 
322 | Kewenangan Pemberian Izin Penggunaan Ruang Bawah Tanah dalam Proyek PT Mass Rapid Transit Jakarta

This page is intentionally left blank 